\title{
Moving on from a judicial preference for mediation to embed appropriate dispute resolution
}

\author{
MASOOD AHMED
}

University of Leicester

\begin{abstract}
This paper critically considers judicial approaches to and promotion of mediation within the English civil justice system. It argues that the overzealous judicial emphasis on mediation in the ADR jurisprudence has restricted the wider concepts of ADR and 'dispute resolution' which in turn bas created what the author terms 'judicial mediation bias'. The paper critically explores these issues through an analysis of the ADR jurisprudence, with a focus on key Court of Appeal ADR authorities, and successive civil justice reforms. The paper makes proposals for reform, including the potential use of stages one and two of Lord Justice Briggs' online court to promote a greater application of a variety of ADR procedures, in particular, judicial early neutral evaluation and collaborative dispute resolution.
\end{abstract}

Key words: civil justice system; dispute resolution; alternative dispute resolution; mediation; online court; litigants in person; reform

\section{Introduction}

ver the past quarter of a century, mediation has grown to become an integral part of the civil justice fabric of many common law and civil law jurisdictions. ${ }^{1}$ It is consistently promoted by policymakers ${ }^{2}$ and the courts for its economic and practical virtues as compared with costly and lengthy court adjudication. ${ }^{3}$ Some members of the senior judiciary in England and Wales have gone to great lengths to emphasise the growing importance of mediation within the civil justice system. Indeed, Mr Justice Lightman controversially referred to alternative dispute resolution (ADR), with specific reference to

* I am very grateful to Lizzie Iron and the two anonymous referees for their helpful comments on earlier drafts of this paper. The usual disclaimer applies.

1 Examples of common law jurisdictions which have an established history of mediation and mandatory forms of mediation include Australia, Canada and the USA. Singapore recently enacted the Singapore Mediation Act 2017 and the Republic of Ireland recently passed the Mediation Act 2017. Italy, France and China are examples of civil law jurisdictions with an established history of mediation. See S Ali, Court Mediation Reform: Efficiency, Confidence and Perceptions of Justice (Edward Elgar 2018).

2 In the family context, mediation has been formally introduced by s 10(1) of the Children and Families Act 2014.

3 For example, see the comments of Lord Justice Jackson praising mediation as an important cost-saving mechanism in his Review of Civil Litigation Costs: Final Report (TSO 14 January 2010) ch 36, 355. 
mediation, as being 'at the heart of today's civil justice system.' ${ }^{4}$ More recently, the Civil Justice Council ADR Working Group explained that mediation 'is the principal process for us to consider, operating in the direct shadow of the civil courts. Almost all of the Court decisions about ADR have been about mediation. ${ }^{5}$ Finally, mediation has found favour on the regional and international levels with the EU Mediation Directive ${ }^{6}$ and the recently proposed Convention on the Enforcement of Mediation Settlements. ${ }^{7}$

As government austerity policies ${ }^{8}$ continue to have a stranglehold on public expenditure on the justice system, ${ }^{9}$ the judiciary has embraced mediation as the most preferred ADR process in diverting cases away from the over-burdened and underresourced civil courts. ${ }^{10}$ This strong judicial preference for and promotion of mediation has been consistently reflected in the evolving ADR jurisprudence, ${ }^{11}$ extrajudicial statements $^{12}$ and successive civil justice reforms. Mediation featured prominently in Sir Rupert Jackson's Review of Civil Litigation Costs and was praised for its role in controlling litigation costs for the parties and the courts. ${ }^{13}$ More recently, mediation was a major focus of Lord Justice Briggs' (as he then was) recent Civil Courts Structure Review (CCSR) ${ }^{14}$ in which he proposed the introduction of an online court, ${ }^{15}$ now called the Online Civil Money Claims (OCMC), ${ }^{16}$ for the resolution of low-value money claims, with an enhanced focus on settlement. ${ }^{17}$

4 Hurst v Leeming [2002] CP Rep 59. The combined effect of delay, expense and complexity - the enemies of justice - have severely restricted access to justice. See the comments in Lord Justice Briggs, Civil Courts Structure Review: Interim Report (Judiciary of England and Wales 2015) (CCSR Interim Report); Lord Justice Briggs, Civil Courts Structure Review: Final Report (Judiciary of England and Wales 2016) (CCSR Final Report).

5 ADR and Civil Justice: CJC ADR Working Group Final Report (CJC ADR Working Group November 2018) <www.judiciary.uk/wp-content/uploads/2018/12/CJC-ADRWG-Report-FINAL-Dec-2018.pdf>.

6 Directive 2008/52/EC of the European Parliament and of the Council of 21 May 2008 on certain aspects of mediation in civil and commercial matters. Although recognising the efforts of Member States in implementing the Directive, the European Parliament in its 2017 Report on the Mediation Directive recommended, inter alia, the need for greater publicity and education of mediation within Member States as well as the need for greater quality control of mediators. It also welcomed the introduction of mediation in family disputes.

7 This is to be called the Singapore Mediation Convention. See <wwwsingaporeconvention.org >. For a critical review of the proposals, see M Ahmed, 'Reflections on the UNCITRAL Convention on the Enforcement of Mediation Settlement Agreements and Model Law' (2019) 2 (May) Lloyd's Maritime and Commercial Law Quarterly 259-69.

8 See 'Ministry of Justice's Settlement at the Spending Review 2015' (Press Release 25 November 2015) <www.gov.uk/government/news/ministry-of-justices-settlement-at-the-spending-review-2015>.

9 For example, from 2010-11 to 2015-16 there has been a 34\% cut in spending by the Ministry of Justice. See The Crisis in the Justice System in England and Wales: The Bach Commission on Access to Justice Interim Report (Fabian Society November 2016).

10 CJC ADR Working Group Interim Report (n 5).

11 Recent pro-mediation cases include Garritt-Critchley v Ronnan [2014] EWHC 1774 (Ch) and Thakkar v Patel [2017] EWCA Civ 117, although see Gore v Nabeed [2017] EWCA Civ 369 in which Patten LJ appeared to adopt a divergent approach to the earlier decision in Thakekar.

12 Lord Neuberger, ‘A View from on High' (Civil Mediation Conference 2015).

13 Jackson (n 3) ch 36.

14 CCSR Interim Report and CCSR Final Report (n 4).

15 The official name of the online court is the Online Civil Money Claims.

16 The OCMC is currently subject to a pilot. The rules governing the pilot are set out in CPR 51R.

17 For a collection of essays critically discussing various aspects of the proposed online system, see P Cortes, 'The Online Court: Filling the Gaps of the Civil Justice System?' (2017) 36(1) Civil Justice Quarterly109; M Ahmed, 'A Critical View of Stage 1 of the Online Court' (2017) 36(1) Civil Justice Quarterly 12; and J Sorabji ‘The Online Solutions Court - a Multi-door Courthouse for the 21st century' (2017) 36(1) Civil Justice Quarterly 86. 
It has, therefore, become increasingly noticeable that strong judicial promotion of mediation has elevated it as the pre-eminent ADR procedure in the resolution of civil disputes. This is understandable given the well-known virtues of mediation over litigation. A successful mediation - a mediation which has resulted in a settlement between the parties - saves the parties from incurring substantial and unpredictable litigation costs and preserves the courts' finite resources. It provides the parties with a voluntary, non-adjudicative process and empowers them to craft a solution for their disputes which works for them, something which the court process cannot provide. ${ }^{18}$

Although there can be no dispute concerning the rationale for strong judicial preference for mediation, this has created 'judicial mediation bias'. Judicial mediation bias entails the overzealous judicial focus on mediation as the most preferred ADR option, without sufficient consideration of other ADR procedures which have been neglected and underused. Judicial mediation bias has had an adverse impact on the development of ADR - both as regards the use of other forms of ADR, and in relation to building the skills for and availability of these alternatives. From a jurisprudential perspective, the case law reflects the development of a narrow and distorted concept of ADR which simply equates ADR to mediation. This distorted understanding of the concept of ADR has been partly reinforced by the judiciary's tendency to refer to ADR as simply amounting to mediation, rather than distinguishing between the various ADR procedures and thereby promoting a wider appreciation of the concept and nature of these procedures. This is particularly concerning in respect of Court of Appeal authorities because of that court's responsibilities in monitoring, developing and reforming civil procedure.

To remedy these shortcomings, this paper will argue for a judicial cultural shift and significant procedural changes, so that ADR is promoted and used in its widest sense. It will be argued that stage two of the OCMC, which is currently under construction and which will incorporate an opt-out mediation stage, provides the greatest potential to remedy the ills caused by judicial mediation bias so that, as the jurisdiction of the OCMC expands in the future beyond small value money claims, a range of ADR procedures, including early neutral evaluation (ENE) and collaborative dispute resolution (CDR), are embedded and used. In particular, the recent Court of Appeal decision Lomax v Lomax, ${ }^{19}$ which held that the courts could, as part of their case management powers, ${ }^{20}$ compel parties to engage with judicial ENE, provides a new impetus for a judicial culture shift and greater integration of ADR within the civil justice system. ${ }^{21}$ It will also be argued that the recent Courts and Tribunals (Judiciary and Functions of Staff) Act 2018, which provides the flexibility for judges to be deployed across a range of cases, provides impetus to incorporate and encourage judicial-ENE at stage two of the OCMC.

It should be noted from the outset that the paper is only concerned with certain nonadjudicative ADR procedures: those procedures which assist the parties in reaching a settlement but allow the parties to withdraw from the process before a binding settlement

18 S Blake, J Browne and S Sime, A Practical Approach to Alternative Dispute Resolution (3rd edn, Oxford University Press 2014); and S Blake, J Brown and S Sime, The Jackson ADR Handbook (2nd edn, Oxford University Press 2016).

19 Lomax v Lomax [2019] EWCA Civ 1467.

20 Civil Procedure Rule 3.1(2)(m).

21 CPR 3.1(2)(m) provides that the court may 'take any other step or make any other order for the purpose of managing the case and furthering the overriding objective, including hearing an Early Neutral Evaluation with the aim of helping the parties settle the case'. See the comments of HHJ Birss (as he then was) explaining that ENE forms part of the courts' case management powers in Fayus Inc v Flying Trade Group plc [2012] EWPCC 43. In Frey v Labrouche [2012] EWCA Civ 881 at [41] Lord Neuberger made it clear that judges are permitted to express preliminary views as to points at issue. 
agreement is concluded. It is not concerned with adjudicative forms of ADR: that is those forms of ADR procedures which the parties have voluntarily chosen and where a third party reaches a binding decision. In this regard, arbitration and the compulsory adjudication scheme for (non-dwelling) construction disputes ${ }^{22}$ and other forms of adjudicative ADR are not considered. ${ }^{23}$ Ombudsman services, which can result in a binding decision, are also not considered. Further, this paper does not engage with the well-trodden ground concerning the impact mediation may have on the development of the law; ${ }^{24}$ the types of 'justice' that mediation offers to the parties; ${ }^{25}$ whether mediation should be made compulsory; ${ }^{26}$ the potential dangers of imbalances of power between the parties during the mediation process; ${ }^{27}$ the confidential nature of mediation; ${ }^{28}$ nor whether mediators should be regulated. ${ }^{29}$

Part one of the paper will analyse the concept of ADR, the wider notion of 'dispute resolution' and various non-adjudicative ADR procedures including ENE and CDR. Part two will discuss the promotion of mediation by successive English civil justice reforms. Part three will review ADR jurisprudence and critically analyse the emergence of judicial mediation bias and its consequences. Finally, part four will offer proposals for reforms.

\section{A variety of ADR procedures and a wider concept}

To understand the dominant position which mediation currently occupies within the civil justice system and how it has been promoted by the senior judiciary, it is important to appreciate what is meant by ADR (conceptually and procedurally) and what is meant by the wider notion of 'dispute resolution'. A discussion of these concepts will help to illustrate the existence of a narrow description of ADR and dispute resolution and the consequential emergence of judicial mediation bias; and the need for reform.

\subsection{ADR PROCEDURES AND THE WIDER CONCEPT OF 'DISPUTE RESOLUTION'}

There is no universally agreed definition of 'alternative dispute resolution' but, in its most simple terms, ADR refers to the resolution of disputes (for the purposes of this paper, civil disputes) through procedures other than the formal court process. ${ }^{30}$ ADR has been varyingly described by the senior judiciary as, on the one hand, being at the 'heart of our civil justice system' 31 and, on the other, as being 'supplementary' or as running 'in parallel'

22 Housing Grants, Construction and Regeneration Act 1996; Scheme for Construction Contracts (England and Wales) Regulations 1998, SI 1998/649.

23 The Professional Negigence Adjudication Scheme para 6(i) of the Professional Negligence Pre-action Protocol.

24 O Fiss, 'Against Settlement' (1984) 93 Yale Law Journal 90; H Genn, 'What Is Civil Justice For? Reform, ADR, and Access to Justice' (2013) 24(1) Yale Journal of Law and the Humanities 397.

25 Fiss (n 24); Genn (n 24).

26 D Girolamo, 'Rhetoric and Civil Justice: A Commentary on the Promotion of Mediation without Conviction in England and Wales' (2016) 35(2) Civil Justice Quarterly 162.

27 O Gazal-Ayal and R Perry, 'Imbalances of Power in ADR: The Impact of Representation and Dispute Resolution Method on Case Outcomes' (2014) 39 Law and Social Inquiry 791.

28 B Clarke and A Agapiou, 'The Practical Significance of Confidentiality in Mediation' (2017) 37(1) Civil Justice Quarterly 74.

29 Mike Whitehouse, 'Regulating Civil Mediation in England and Wales: Towards a “Win-win” Outcome' (2017) 2(1) Mediation Theory and Practice; Mike Whitehouse, 'Mediation and the Art of Regulation' (2017) 2(1) Mediation Theory and Practice 69-83.

30 The CEDR defines ADR as: 'A body of dispute resolution techniques which avoid the inflexibility of litigation and arbitration, and focus instead on enabling the parties to achieve a better or similar result, with the minimum of direct and indirect cost."

31 Hurst (n 4). 
to judicial determination. ${ }^{32}$ Despite these varying judicial opinions on the role played by $\mathrm{ADR}$, it is clear that there has been a consistent acceptance among the senior judiciary that court adjudication is no longer the primary means by which all disputes should be resolved. This acceptance of a paradigm shift in dispute resolution is consistent with Lord Woolf's revolutionary reforms ${ }^{33}$ which ushered in a new philosophy that the civil justice system should primarily be concerned with the settlement of disputes.

As acceptance of ADR has grown, some among the senior judiciary have adopted a cautious approach in embracing ADR and have made powerful arguments in making clear that ADR is 'supplementary' to court adjudication. Lord Neuberger has consistently explained that the courts, not private forms of dispute resolution, fulfil the function of the state in the administration of equity and law. Although arbitration and other forms of ADR can secure justice for individuals, 'they do so because they exist within the framework of law and enforcement by formal adjudication. Without formal adjudication they would be mere epiphenomena.' 34 Similarly, Lord Briggs has stated that court adjudication 'remains an essential guarantor of the rule of law'. 35

A further issue which requires attention is the concept of 'dispute resolution'. Although ADR refers to those procedures that are separate to the court process, the concept of 'dispute resolution' is wider. It refers to all procedures available in the resolution of disputes - litigation and ADR. This wider concept of dispute resolution is echoed in the late Professor Frank Sander's seminal lecture at the Pound Conference in 1976 where he famously spoke of his vision of the court being a 'dispute resolution centre', later coined the 'multi-door courthouse' in which it adopts a pro-active and facilitative approach in 'screening' and allocating disputes to an appropriate dispute resolution process. ${ }^{36}$ Sanders' vision reflected the idea that court adjudication was not the only means through which disputes could be resolved - they could and should be resolved through a variety of appropriate dispute resolution procedures.

The wider concept of 'dispute resolution' was not easily transferred into the English civil justice system. The Woolf and Jackson Reforms adopted a compartmentalised approach to the concept of the resolution of civil disputes as being either through litigation or ADR, with a focus on mediation as the preferred ADR procedure. The wider concept that dispute resolution encompassed all procedures which may resolve disputes remained absent from the English civil justice landscape until Briggs LJ's Chancery Modernisation Review in 2013. ${ }^{37}$ Briggs LJ was the first to advocate the need for a judicial culture shift in the management of disputes so that cases are managed to 'a resolution' which would include ADR procedures as well as litigation. Briggs LJ's call for a culture shift in the judicial management of disputes was also prevalent in his CCSR. ${ }^{38}$ However, this wider application of the concept of ADR and dispute resolution is inherently absent from the jurisprudence. As will be demonstrated, ADR is perceived as simply meaning

32 Neuberger (n 12).

33 The Rt Hon Lord Woolf, Access to Justice Interim Report (Lord Chancellor's Department 1995) ch 2, para 7(a) (Interim Report) and the Rt Hon Lord Woolf, Access to Justice Final Report (Lord Chancellor's Department 1996) (Final Report).

34 Lord Neuberger MR, 'Equity, ADR, Arbitration and the Law: Different Dimensions of Justice' (Fourth Keating Lecture, Lincoln's Inn, 19 May 2009).

35 CCSR Interim Report (n 4).

36 See F Sander, 'Varieties of Dispute Processing' (1976) 70 Federal Rules Decisions 111-34; F Sander, 'The Multi-door Courthouse' (1976) 3 Barrister 18.

37 Lord Justice Briggs, Chancery Modernisation Review: Final Report (Judiciary of England and Wales December 2013) para 5.

38 CCSR Interim Report (n 4) para 2.22. 
mediation and 'dispute resolution' as either litigation or mediation. This is particularly evident from the extrajudicial comments of Sir Gavin Lightman, who controversially spoke of ADR, with a focus on mediation, as being 'at the heart of today's civil justice system'. ${ }^{39}$ In his speech 'The Civil Justice System and the Legal Profession - The Challenges Ahead', 40 Sir Gavin argued that 'a mediation culture is vital today where the alternative is financially crippling and socially disruptive'. ${ }^{41}$ In another speech he spoke of the benefits of mediation affording 'a palliative' to those, particularly litigants in person (LiPs), who could not afford the cost and risk of litigation. Mediation provided 'the chance of the approximation to justice'. ${ }^{42}$

With respect, Sir Gavin's call for a 'mediation culture' being 'vital' is not convincing. Although it is accepted that mediation has its economic and practical virtues, to call for a culture change which focuses only on mediation undermines the broader need to promote a culture of settlement through a variety of ADR procedures. It fundamentally creates two streams in the resolution of disputes within the civil justice system: litigation or mediation. This is not consistent with the wider notions of ADR and dispute resolution - but is consistent with the 'tunnel vision' of ADR that is evident from the jurisprudence.

Further, although it is true that litigation is costly for ordinary citizens, they should not be channelled into resolving their disputes exclusively through mediation. The focus should continue on increasing access to justice and that can be achieved by educating parties about dispute resolution and guiding parties to the most appropriate dispute resolution procedure. This issue will be explored further when reflecting on the CCSR and the OCMC.

\subsection{ADR - A VARIETY OF PROCEDURES}

\subsubsection{Mediation; conciliation; negotiation}

ADR also encompasses a variety of alternative procedures. The common forms of ADR procedures referred to in the CPR include mediation and conciliation; negotiation or settlement meetings; 43 and ENE. ${ }^{44}$ Although procedures other than mediation are mentioned in the CPR and in the pre-action protocols, reference to mediation remains dominant in the case law and reforms while other procedures, such as ENE, are severely underused and ignored. CDR, common in North America for family matters and now increasingly used in divorce matters in England, will also be considered.

Negotiation is a non-adjudicative, confidential and flexible ADR process which can be conducted by the parties and/or by their respective lawyers. It is the most common form of dispute resolution 45 and allows the parties to retain complete control of the outcome. Mediation has similar features to negotiation but, unlike negotiation, it involves a thirdparty neutral - the mediator - who seeks to facilitate what is essentially a negotiation

39 Hurst (n 4).

40 G Lightman, 'The Civil Justice System and Legal Profession - The Challenges Ahead' (2003) 22 Civil Justice Quarterly 235.

41 Emphasis added.

42 G Lightman, 'Mediation: An Approximation to Justice' (Speech, SJ Berwin Mediation Summer Drinks Reception 28 June 2007) <www.cedr.com/articles/?item=Mediation-an-approximation-to-justice-a-speechby-The-Honourable-Mr-Justice-Lightman>.

43 Sometimes referred to as 'without prejudice meetings'.

44 For a detailed coverage of these and other adjudicative ADR procedures, see Blake et al, A Practical Approach (n 18).

45 Blake et al, Jackson ADR Handbook (n 18) para 216. 
process to resolve a dispute. The parties retain control of the process and are only bound by the final settlement agreement. Conciliation is similar to mediation and involves, like mediation, a neutral third-party conciliator who will either facilitate a compromise or may actively make settlement proposals. Often, due to its similarities to mediation, conciliation is, as is evident from the CCSR, interchangeably referred to as mediation and vice versa. ${ }^{46}$

\subsubsection{Early neutral evaluation and collaborative dispute resolution}

ENE is a written assessment of the issues in dispute conducted by an independent third party (who may be a judge) who is an expert in the field. The written assessment provides the parties with an indication of the likely strengths and weaknesses of their arguments, which may then assist in an early resolution of the matter. ENE can be provided by organisations or individual specialists (private ENE) or by the courts (judicial-ENE). ${ }^{47}$

Briggs LJ endorsed ENE as a 'valuable tool' for encouraging settlement in a range of Chancery cases. ${ }^{49}$ Further, in Seals $v$ Williams ${ }^{50}$ Norris $\mathrm{J}$ in the Chancery Division described as 'commendable' the parties' legal representatives' proposed use of ENE to the court. Confirming that judges could provide ENE, Norris J outlined the advantages of ENE over mediation in the following terms:

The advantage of such a process over mediation itself is that a judge will evaluate the respective parties' cases in a direct way and may well provide an authoritative (albeit provisional) view of the legal issues at the heart of the case and an experienced evaluation of the strength of the evidence available to deploy in addressing those legal issues. The process is particularly useful where the parties have very differing views of the prospect of success and perhaps an inadequate understanding of the risks of litigation itself. ${ }^{51}$

The Civil Procedure Rule Committee amended ${ }^{52}$ Civil Procedure Rule (CPR) 3.1(2)(m) to make express reference to an ENE hearing. CPR r.3.1(2)(m) provides that the court may, as part of its general case management powers:

Take any other step or make any other order for the purpose of managing the case and furthering the overriding objective, including hearing an Early Neutral Evaluation with the aim of helping the parties settle the case. 53

Despite judicial praise of ENE, Briggs LJ in his CCSR voiced concern that it was being offered 'on an infrequent ad hoc basis by various courts'. ${ }^{54}$ This has also been noted by the Civil Justice Council ADR Working Party, which recently conducted a review of the

46 CCSR Interim Report (n 4).

47 For example, the Centre for Effective Dispute Resolution (CEDR) provides private ENE services. Other private organisations providing ENE services include the Academy of Experts, the ADR Group, the City Disputes Panel, the Chartered Institute of Arbitrators, the London Court of International Arbitration and the Royal Institute of Chartered Surveyors.

49 Briggs (n 37).

50 [2015] EWHC 1829 (Ch). See also Fayus Inc v Flying Trade Group plc [2012] EWPCC 43.

51 Ibid.

52 This was incorporated into CPR 3.1(2)(m) by the Civil Procedure (Amendment No 4) Rules 2015 and came into effect on 1 October 2015.

53 Emphasis added.

54 CCSR Interim Report (n 4) para 2.91, where Briggs LJ noted: 'the District Judges who undertake both Family and Chancery case management outside London have successfully introduced a measure of early neutral evaluation into Chancery litigation about family property (such as TOLATA and Inheritance Act claims) by cross-application of their experience in conducting financial dispute resolution hearings in family cases'. 
provision of ADR within the civil justice system, when it noted: 'ENE seems to have been rarely used indeed. The number of private ENEs of which the Working Group are aware is vanishingly small. 55 This is surprising given the benefits ENE offers, especially where the parties are so entrenched in their positions that a mediator cannot dislodge them and move them towards a settlement. The ENE process also has the advantage of providing 'authority' to the evaluation of the parties' positions and, as noted above, has the ability either to move the parties to a settlement or, at the very least, narrow the issues which may assist case management or settlement at a later stage in the litigation. This could be a particularly useful aid to LiPs, many of whom face court proceedings with little understanding of legal process and no training in forming legal arguments. It may, however, be argued that ENE is potentially more expensive and time-consuming as compared with mediation because it requires the parties to make appropriate disclosure of information and documents without which the process would be futile. Certainly, there is force in this argument. Although disclosure is a cornerstone of English civil procedure, it can be a time-consuming and expensive exercise, ${ }^{56}$ and yet without appropriate disclosure the evaluator would be unable to provide his or her opinion on the merits of the parties' respective positions. But this is equally true of mediation, expert determination and construction adjudication: these ADR procedures rely on the disclosure of documents for the process to work effectively. Further, litigating parties are obliged to engage with the pre-action protocols before issuing court proceedings and those protocols oblige the parties to make early disclosure of documents. Thus, disclosure of documents during the pre-action stage (including the detailed letters of claim and reply setting out the parties' arguments) can be used during the ENE process thereby reducing the time and cost of further disclosure exercise.

Finally, mention should be made of CDR which has had little attention in the English scholarly ADR literature. ${ }^{57}$ CDR has its origins in North America and is slowly being used in family divorce matters in England. CDR requires the parties and their lawyers to commit to working toward resolution without going to court. ${ }^{58}$ The commitment allows any of the parties to withdraw from the process before an agreement is reached. The parties then use methods which are intentionally focused on settlement by design. The parties and lawyers accomplish this through a series of collaborative meetings, in which all the substantive negotiations take place. The meetings address at least five key tasks, each building on the previous one: discussion and agreement upon the rules of the collaborative process used; voluntary and open sharing and exchange of all relevant information; identifying interests and goals of the parties; developing options for resolution, using neutral experts when appropriate; and determining the terms of the resolution and reducing them to a settlement agreement.

Collaborative processes are confidential and allow the parties and their lawyers to concentrate their efforts on satisfying their interests as well as those of the other party.

55 CJC ADR Working Group Interim Report (n 5) para 3.9.

56 In May 2016, the then Chancellor of the High Court, Sir Terence Etherton, established a Working Group in response to widespread concerns regarding the excessive scale and costs of disclosure. A Working Party, led by Lady Justice Gloster, published its report in 2019 in which it made a number of recommendations which are subject to a pilot scheme which is currently underway in the Business and Property Courts of England and Wales. See <www.judiciary.uk/announcements/disclosure-proposed-pilot-scheme-for-the-business-andproperty-courts $>$.

57 The basic elements of CDR are described on the webpages of some family law firms.

58 See J Lande, 'The Revolution in Family Law Dispute Resolution' (2012) 24 Journal of the American Academy of Matrimonial Lawyers 411; J Lande, 'Principles for Policymaking about Collaborative Law and Other ADR Processes' (2007) 22(3) Ohio State Journal on Dispute Resolution 619. 
The lawyers actively work with their clients, advise them, advocate on their behalf and help to facilitate the process of resolution. Due to its flexible nature and its focus on resolving disputes in both parties' interests, CDR is popular in the USA in family matters and is being used in divorce matters in England. While the process can appear costly, it may, however, save costs overall, and there is clearly scope for CDR to extend beyond family disputes and cover high-value civil disputes which may require expert input and involve complex legal and factual issues. The commitment element is a distinguishing and significant feature as compared with other, more conventional, ADR procedures such as settlement meetings, which are used in engineering and construction disputes: the commitment is given by both parties to resolve and not to litigate and this has the effect of focusing the minds of the parties from the outset on working with each other to reach a solution to which all the parties have contributed. This active involvement in the process provides the parties with a greater sense of empowerment over both the process and final outcome and can lead to higher levels of satisfaction.

There is also recent empirical data from dispute resolution stakeholders (including corporates and individuals) that demonstrate strong support for more collaborative forms of dispute resolution. The Global Pound Conference Series ${ }^{59}$ collated empirical data from over 4000 respondents across the spectrum of dispute resolution stakeholders, at 28 conferences across 24 countries worldwide. One of the major themes that emerged from the data was that respondents expected greater collaboration from legal advisors (whether in-house general counsel or external panel lawyers) in dispute resolution as opposed to adversarial processes. This trend is evidence of the emergence of a 'second dispute resolution culture shift': the first was a shift from litigation to a wider understanding of dispute resolution which encompassed ADR. The second dispute resolution culture shift is one away from adversarial types of ADR procedures (principally arbitration) to those which are collaborative and focus on the opposing parties working together constructively to resolve disputes.

As will be explored in part four, ENE and CDR should not only be embraced and promoted by the judiciary, but should be embedded within stage two of the OCMC.

\section{Dispute resolution, ADR and mediation in civil justice reforms}

This part considers how successive civil justice reforms have approached the concepts of dispute resolution, ADR and the promotion of mediation. A review of recent reforms demonstrates a wider judicial appreciation and understanding of a range of ADR procedures and, with Briggs LJ's Chancery Modernisation Review and CCSR, the emergence of a judicial understanding of dispute resolution which corresponds with that advocated by Sander. That understanding is also strongly echoed in Briggs LJ's CCSR. However, as ADR has gradually become embedded within the civil justice system since the Woolf Reforms, later ADR jurisprudence reflects a strong judicial bias towards mediation as the default ADR option to litigation.

\subsection{The Reforms - WoOlf, JACKSON AND BRIGGS}

Through his revolutionary reforms, Lord Woolf 60 gave formal effect to his philosophy that the aim of the civil justice system should be the settlement of disputes rather than engagement with the expensive and complex adversarial court process. He achieved this

59 The Global Pound Conference Series 2016-17: Shaping the Future of Dispute Resolution and Improving Access to Justice <www.imimediation.org/2015/10/19/global-pound-conference-launch-shaping-the-futureof-dispute-resolution-improving-access-to-justice/ $>$.

60 Woolf, Interim Report (n 29) ch 2, para 7(a). 
by formally incorporating ADR within the CPR and making it part of the court's duty to further the overriding objective. ${ }^{61}$ That duty includes the court's obligation to encourage the parties to use ADR procedures and to help by facilitating the use of such procedures. The ADR obligation is also incorporated within the system of pre-action protocols, ${ }^{62} \mathrm{a}$ framework governing parties' behaviours before proceedings can be issued, which encourages early disclosure of documents and aims to promote early settlement. It should be noted that the majority of pre-action protocols list a number of ADR procedures which the parties may choose to engage with. Those procedures include: negotiation, mediation, arbitration, early neutral evaluation and the ombudsman systems. ${ }^{63}$

In his Review of Civil Litigation Costs Final Report, Jackson LJ dedicated a whole chapter to $\mathrm{ADR}$ and the beneficial role mediation plays in reducing disproportionate costs. Jackson LJ explained that ADR was 'under-used' and 'Its potential benefits are not as widely known as they should be.' It was noted that mediation and joint settlement meetings (a form of negotiation) were 'highly efficacious means of achieving a satisfactory resolution of many disputes, including personal injury claims'. ${ }^{64}$ Although his Lordship's primary focus was on mediation, he also gave attention to the practical and economic virtues of joint settlement meetings (especially when discussing the Pre-action Protocol for Construction and Engineering Disputes) and, to a limited extent, ENE.

It was Briggs LJ who advocated a wider notion of ADR and one which echoed the vision of Professor Sander's multi-door courthouse. In his Chancery Modernisation Review, Briggs LJ argued that, rather than simply managing cases to trial, the courts should take a more active approach in the encouragement, facilitation and management of dispute resolution in the widest sense, including ADR as part of that process. Briggs LJ's philosophy is to be welcomed because it gives effect to the wider notion of dispute resolution that encompasses all means of resolving disputes and provides the way forward to promote and encourage the greater use of the various ADR procedures available to the courts and the parties.

\subsection{The Online Civil Money Claims}

Briggs LJ's dispute resolution philosophy features prominently in his radical proposal for an online court for the resolution of low-value money claims. The proposals for an online court and the wider reform proposals made by Briggs LJ were to finally remedy 'The single, most pervasive and intractable weakness of our civil justice courts' which is 'that they simply do not provide reasonable access to justice for any but the most wealthy individuals. ${ }^{35}$

The Civil Justice Council Online Dispute Resolution Advisory Group suggested a three-tier online court for low-value claims, with an enhanced focus on online dispute

61 CPR 1 sets out the overriding objective which is the central pillar of the CPR. Rule 1 states: '(1) These Rules are a new procedural code with the overriding objective of enabling the court to deal with cases justly and at proportionate cost.' Dealing with cases 'justly and at proportionate cost' is detailed in CPR 1(2) which states '(2) Dealing with a case justly and at proportionate cost includes, so far as is practicable - (a) ensuring that the parties are on an equal footing; (b) saving expense; (c) dealing with the case in ways which are proportionate - (i) to the amount of money involved; (ii) to the importance of the case; (iii) to the complexity of the issues; and (iv) to the financial position of each party; (d) ensuring that it is dealt with expeditiously and fairly; (e) allotting to it an appropriate share of the court's resources, while taking into account the need to allot resources to other cases; and (f) enforcing compliance with rules, practice directions and orders.'

62 There are currently 16 pre-action protocols. For a complete list, see <www.justice.gov.uk/courts/procedurerules/civil/protocol>.

63 See, for example, the General Pre-action Protocol, para 10.

64 Jackson (n 3) ch 36, 355.

65 CCSR Interim Report (n 4) para 51. 
resolution (ODR). Briggs LJ proposed the introduction of a three-stage online court which would, he explained, form 'part of the mainstream civil justice system, rather than a tribunal or a structure for arbitration or ADR'. 66

Briggs LJ explained the three-stage structure of his online court as follows:

... stage 1 will consist of a mainly automated process by which litigants are assisted in identifying their case (or defence) online in terms sufficiently well ordered to be suitable to be understood by their opponents and resolved by the court, and required to upload (i.e. place online) the documents and other evidence which the court will need for the purpose of resolution. Stage two will involve a mix of conciliation and case management, mainly by a Case Officer, conducted partly online, partly by telephone, but probably not face-to-face. Stage 3 will consist of determination by judges, in practice DJs or DDJs, either on the documents, on the telephone, by video or at face-to-face hearings, but with no default assumption that there must be a traditional trial. ${ }^{67}$

In his Interim Report, Briggs LJ spoke more generally of the need to make stage two 'conciliation' a 'culturally normal' part of the civil court process, but appeared to focus his attention on the small claims mediation procedure which currently exists. ${ }^{68}$ However, in his Final Report, Briggs LJ appeared to abandon his initial recommendations that the ADR procedure at stage two should be mediation. Rather, he modified his position to reflect a wider approach to and understanding of both dispute resolution and ADR procedures when he explained that stage two would make conciliation a culturally normal part of the civil court process and that ODR, judicial-ENE or private mediation may form part of that stage. Briggs LJ also explained that the court officer at stage two would be tasked with working with the parties to ascertain the most appropriate ADR method to resolve the dispute. ${ }^{69}$

By forming an integral part of the existing civil justice architecture, Briggs LJ's online court closely resembles Sander's multi-door courthouse. It seeks to create a fully functional dispute resolution forum which incorporates a variety of ADR procedures within the litigation process. In this regard, it goes further than the Woolf Reforms, which were instrumental in providing a formal role for ADR within the civil justice system. Briggs LJ's proposed online court and, in particular stage two, follows the Woolf Reforms in providing ADR with a formal and integrated function within the procedural architecture, but goes further in providing ADR with an enhanced status. This is underlined by the proposed pro-active role the court officer will play in working with the parties to consider ADR and choose the most appropriate procedure. Briggs LJ's vision also reflects a wider understanding of the concept of 'dispute resolution' which embraces ADR as well as formal court adjudication.

Despite the comprehensive approaches taken by the civil justice reforms, there has been a failure within the civil justice system to give effect to the wider notions of 'dispute resolution' and ADR procedures. This is particularly evident from the initial findings of the Civil Justice Council ADR Working Party which identified an ADR deficit within the civil justice system and that there has been a failure to effect a culture change both within the judiciary and the wider public. ${ }^{70}$ One element of this ADR deficit, the present writer contends, is the failure of the senior judiciary to advocate, promote and encourage the

66 Ibid ch 6.

67 Ibid para 76.

68 Ibid para 6.13.

69 CCSR Final Report (n 4) paras 6.112-113 and 7.22.

70 CJC ADR Working Group Interim Report (n 5). 
use of a variety of ADR procedures, including ENE, through the jurisprudence. This is in contrast to the wider ADR and dispute resolution approach advocated by successive civil justice reforms. It is to the ADR jurisprudence to which we now turn our attention.

\section{ADR jurisprudence and judicial mediation bias}

This part reflects on and critically considers ADR jurisprudence, primarily from the Court of Appeal, and illustrates how the notion of judicial mediation bias has developed as a consequence of judicial focus and (over)emphasis on mediation as the pre-eminent and default ADR procedure to litigation. While some of these cases involved one of the parties proposing mediation, and therefore the court's focus was on mediation, it will be argued that this should not prevent or restrict the court's reference to the wider notion of dispute resolution. Neither should it prevent the court, especially the Court of Appeal which is responsible for the reform and development of civil procedure, from providing otherwise valuable judicial comments and guidance on the possible relevance of the wider ADR procedures available to the parties. Finally, it should not follow that, because a particular case is concerned with mediation, the Court of Appeal should demonstrate overzealous judicial preference for mediation, since it is this which has resulted in judicial mediation bias with mediation perceived as the preferred ADR default to litigation.

The general ADR approach of the Woolf Reforms and the relevant provisions within the CPR reflect the fundamental principle of party autonomy in allowing the parties themselves to choose the most appropriate ADR process. ${ }^{71}$ The 'party choice' approach is also reflected through the early ADR jurisprudence following the implementation of the Woolf Reforms. In Dyson v Leeds City Council, ${ }^{72}$ an early ADR decision of the Court of Appeal, Lord Woolf MR lamented the disproportionate costs the parties had incurred during the litigation. Without preference for a particular type of ADR procedure, his Lordship commented on the suitability of the matter for resolution through ADR when he said 'we should encourage the parties to use an alternative dispute resolution procedure to bring this unhappy matter to the conclusion it now deserves sooner than later'. ${ }^{73}$ Lord Woolf MR's ADR message to the Court of Appeal and lower courts is that the courts should adopt a more proactive ADR stance by engaging in an ADR dialogue with the parties, encouraging the use of ADR and possibly recommending an appropriate ADR procedure. What it does not do is provide courts with the discretion to unilaterally recommend and impose a particular ADR procedure onto the parties, which would restrict party autonomy. Thus, it is similar to the functions which the court officer is likely to play at stage two of Briggs LJ's online court - a function which will see the parties engaging in a positive and proactive ADR dialogue.

In Cowl v Plymouth City Council, 74 another early ADR Court of Appeal authority, Lord Woolf MR called for the use of the court's new case management powers pursuant to the $\mathrm{CPR}$, to encourage the parties to engage in settlement discussions 'with the minimum involvement of the courts'. His Lordship made clear that the courts could require the parties to provide an explanation as to the steps taken to try to settle the matter:

To achieve this objective the court may have to hold, on its own initiative, an inter parties hearing at which the parties can explain what steps they have taken to resolve the dispute without the involvement of the courts. In particular the parties should

71 For example, CPR 1, the pre-action protocols and CPR 26.

72 [2000] CP Rep 42.

73 Ibid (emphasis added).

74 [2001] EWCA Civ 1935. 
be asked why a complaints procedure or some other form of alternative dispute resolution has not been used or adapted to resolve or reduce the issues which are in dispute. ${ }^{75}$

Lord Woolf MR in both Dyson and Cowl encouraged the parties to engage in ADR procedures without indicating a preference for any one type of procedure. In Cowl he refers to a complaints procedure and 'some other form of alternative dispute resolution', and in Dyson he speaks more generally of 'settlement discussions', which may assist the parties in the resolution of their dispute.

Early signs of strong judicial preference for mediation began to emerge in the leading case of Dunnett $v$ Railtrack $\mathrm{Ltd}^{76}$ in which the Court of Appeal exercised, for the first time, its powers under the CPR to deprive the successful defendant of its costs for behaving unreasonably in refusing to consider the claimant's proposal to seek settlement through mediation. In Dunnett, the claimant brought an appeal concerning the death of her horses, for which she blamed the defendant rail company for failing to maintain gates from which the horses had escaped onto the railway and died. Schiemann LJ, granting permission to appeal, advised the claimant to engage with 'alternative dispute resolution' to resolve the matter. However, the defendant dismissed the claimant's proposal to explore settlement through ADR. Although the claimant lost the appeal, the Court of Appeal denied the successful defendant its costs because of its failure to consider the claimant's ADR proposal. Brooke LJ, a strong supporter and advocate of mediation, gave the seminal judgment on the issue of costs and ADR, stating that this was:

... a case in which, at any rate before the trial, a real effort should have been made by way of alternative dispute resolution to see if the matter could be satisfactorily resolved by an experienced mediator, without the parties having to incur the no doubt heavy legal costs of contesting the matter at trial. ${ }^{77}$

Brooke LJ held that the overriding objective placed a positive duty on the parties to consider ADR in the resolution of disputes. He dismissed the defendant's justification for dismissing ADR on the grounds that it believed the claimant wanted money by way of settlement, which it was unwilling to pay. Brooke LJ set out the practical and economic benefits of mediation and of deploying the skills of a mediator in resolving disputes where emotions were clearly running high. A warning was sent to the profession in the following terms:

It is to be hoped that any publicity given to this part of the judgment of the court will draw the attention of lawyers to their duties to further the overriding objective in the way that is set out in CPR Pt 1 and to the possibility that, if they turn down out of hand the chance of alternative dispute resolution when suggested by the court, as happened on this occasion, they may have to face uncomfortable costs consequence. ${ }^{78}$

Brook LJ's judgment is the first in which the Court of Appeal did not hesitate to use its new powers under the CPR to penalise a party in costs for failing to discharge its ADR obligations. The judgment is particularly significant because it is the first decision which penalises a successful party in costs and thereby departs from the long-established costs principle that the loser should pay the winner's costs.

An interesting feature of the decision, which has not received scholarly attention thus far, is the use of ADR language in the Dunnett judgment. Like Lord Woolf in Dyson and

75 Ibid (emphasis added).

76 [2002] EWCA Civ 3030.

77 Ibid [10] (emphasis added).

78 Ibid [15]. 
Cowl, Brooke LJ begins by using the term ADR in its general sense and as related to the parties' duties under the CPR with reference to specific aspects of the overriding objective. However, when discussing the missed opportunity of not engaging with ADR, Brooke LJ, within the same sentence, shifts his focus onto mediation and the skills that 'an experienced mediator' could bring in successfully resolving the dispute where emotions were clearly running high. Although the remainder of the judgment uses the term ADR, the majority of it remains focused on mediation. Brooke LJ's judgment can be justifiably criticised for a number of reasons. First, it inappropriately conflates ADR and mediation. Secondly, the judgment assumes that mediation would have been the most appropriate ADR procedure and would have resulted in a successful resolution of the dispute. Clearly, there is no harm in judicial recommendation of an ADR procedure - in some cases this may be particularly welcome for parties who do not understand the nature and process of ADR. Indeed, Lord Woolf in Dyson spoke of the need for the courts to make recommendations. However, the judgment in Dunnett goes beyond judicial recommendation, both in the strength of language used and the focus of the judgment on the nature and virtues of mediation and the role of the mediator. The Court of Appeal could have taken the opportunity to discuss the various ADR options available within the civil justice process, which may equally have been appropriate for the resolution of the parties' dispute. Brooke LJ observed that the emotions of the parties were running high and therefore a mediator would have been best placed to deal with the matter to resolution. However, an equally effective ADR procedure, especially where the emotions of the parties are creating an impenetrable barrier to communication and constructive engagement, is ENE, especially judicial-ENE which provides the parties with an objective expert option on the merits of their positions which may be more acceptable to them than mediation.

Mediation came into even sharper focus in the leading Court of Appeal authority of Halsey v Milton Keynes General NHS Trust. ${ }^{79}$ The effect of the Halsey decision has been to radically enhance the status of mediation as the default ADR procedure for civil disputes. One of the main areas of controversy in Halsey has been Dyson LJ's obiter comments regarding compulsory mediation. While noting the general benefits of mediation, Dyson LJ dismissed the call for the courts to compel parties to engage with mediation. He argued, obiter, that to do so would breach the fundamental rights of litigating parties to access the courts. In support of this position, the Court of Appeal relied on the European Court of Justice (ECJ) case of Deweer $v$ Belgium. ${ }^{80}$ In that case, the claimant agreed to pay an amount in settlement of a fine to state authorities and thereby waived his right to refer the dispute to a tribunal. The ECJ held that the claimant's waiver had not amounted to a violation of his right to a fair trial. However, the Court in Halsey incorrectly assumed that Deweer applied to mediation, which permits the parties to revert to the courts for judicial determination if a matter cannot be settled. Judicial reliance on Deweer demonstrates that the Court of Appeal was confused between the nature of mediation, which is non-adjudicative, and arbitration, which is an adjudicative process that binds the

79 [2004] 1 WLR 3002.

80 (1980) 2 EHRR 439, para 49. See further the leading case of Alassini v Telecom Italia SpA (joined cases C-317320/08) [2010] 3 CMLR 17 ECJ in which the Advocate General Kokott held that a form of compulsory mediation for telecommunications disputes in Italy pursued legitimate objectives in the general interest in the quicker and less expensive resolution of disputes. Advocate General Kokott also held that the measure of requiring parties to engage in settlement discussions before commencing court proceedings was proportionate because no less restrictive alternative existed to the implementation of a mandatory procedure since the introduction of an out-of-court settlement procedure, which is merely optional, is not as efficient a means of achieving those objectives. See also the recent case of Menini Banco Popolare Sopcieta Cooperativa (C-75/16). 
parties to the decision of the arbitrator. Lord Dyson MR appeared to categorise mediation as an adjudicative process, which has the effect of restricting the parties' rights to access the courts. Despite this confusion about the nature of mediation, it continued to be regarded as the default alternative to litigation.

The case of Burchell $v$ Bullard ${ }^{81}$ concerned a small building dispute. In that case, the Court of Appeal found the defendant builder to have behaved unreasonably in rejecting the claimant's invitation to mediate the dispute. Giving the leading judgment of the court, Ward LJ strongly endorsed mediation as an effective alternative to court adjudication when he explained:

Halsey has made plain not only the high rate of a successful outcome being achieved by mediation but also its established importance as a track to a just result running parallel with that of the court system. Both have a proper part to play in the administration of justice. The court has given its stamp of approval to mediation and it is now the legal profession which must become fully aware of and acknowledge its value. ${ }^{82}$

Ward LJ's choice of words is particularly interesting. He refers to the significance of mediation 'running parallel' with the court process, which underscores judicial preference for mediation as the pre-eminent default alternative to litigation - it is perceived as the (only) alternative to litigation and thus creates a two-stream approach to dispute resolution: litigation and mediation. Indeed, this is further reinforced when Ward LJ speaks of the courts giving their 'stamp of approval' which the profession must fully understand and appreciate.

Although mediation's benefits may be obvious, it is not, contrary to the message which Ward LJ's judgment appears to portray, the principal or only ADR method, nor the most appropriate procedure for all civil disputes. Indeed, Burchell could have been more suited to ENE than mediation. ENE, especially judicial-ENE, would have provided the parties with an objective appraisal of the merits of the case earlier on in the dispute and therefore assisted the parties in moving from their entrenched positions towards settlement. A further point to note from Burchell, and similar Court of Appeal authorities such as Dunnett, is that the stern message given by the judiciary is for the profession to 'understand' mediation. That message in itself has the effect of forcing lawyers to focus their attentions on mediation rather than considering ADR procedures which may be more appropriate.

A similar mediation-focused decision was given by the Court of Appeal in Rolf $v$ De Guerin, ${ }^{83}$ which, like Burchell, also concerned a small building dispute. The claimant made various invitations to the defendant builder to enter settlement discussions and, later, mediation, which the defendant rejected. Rix LJ found that the defendant's refusal to mediate was unreasonable, and, as a consequence, the court was entitled to exercise its discretion and make an order as to costs. Rix LJ also observed that small building disputes were appropriate for mediation. Despite acknowledging that mediation may not have produced a solution on the particular facts of Rolf, Rix LJ was nonetheless of the opinion that it was suitable for mediation:

It is possible of course that settlement discussions, or even mediation, would not have produced a solution; or would have produced one satisfactory enough to the parties to have enabled them to reach agreement ... Nevertheless, in my judgment,

81 [2005] EWCA Civ 358.

82 Ibid [43].

83 [2011] EWCA Civ 78. See E Suter, 'Building towards Compulsory Mediation' (2011) 77 Arbitration 375. 
the facts of this case disclose that negotiation and/or mediation would have had reasonable prospects of success. The spurned offers to enter into settlement negotiations or mediation were unreasonable and ought to bear materially on the outcome of the court's discretion, particularly in this class of case. ${ }^{84}$

Rolf, like Burchell and similar cases involving small building disputes in which the Court of Appeal stressed that mediation was highly suitable, appeared to 'carve out' this type of dispute for resolution through mediation. What is surprising, however, is that the Court of Appeal consistently neglects ENE, which would have been equally suited, if not better suited, to the resolution of such small building disputes. A judge conducting ENE would be more effective in providing the parties with an assessment of their arguments. JudicialENE would be highly effective in cases where emotions may be running high, as in Rolf where the defendant was determined to expose the claimant's husband's behaviour to a court, which, he believed, would not be possible in mediation. These Court of Appeal authorities appear to have missed an opportunity to encourage and promote ENE.

In Wright v Michael Wright (Supplies) Ltd 85 Ward LJ gave the leading judgment regarding a dispute where both parties were LiPs. Referring to the difficulties which LiPs may cause to the court process and to judicial case management, Ward LJ made explicit reference to two tracks of dispute resolution when he said that it is not possible to shift intransigent parties off the trial track onto the parallel track of mediation. Both tracks are intended to meet the modern day demands of civil justice. ${ }^{86}$ Ward LJ's words echo those of Sir Gavin Lightman who spoke of mediation being a palliative form of justice to those who could not afford court adjudication. They also reflect senior judicial understanding that the civil justice system consists of litigation and, as an ADR default, mediation, which parties should consider.

The Court of Appeal in PGF $v O M F S,{ }^{87}$ the leading case on ADR since the Halsey decision, took a slightly more nuanced approach, principally because the leading judgment was given by Briggs LJ. In PGF, the claimants made various invitations to the defendants to engage in mediation. The defendants decided to simply ignore the claimant's invitations and were subsequently successful in the litigation. One of the key issues upon which the claimant successfully appealed was costs. The claimant contended that the defendants' conduct in ignoring the claimants' invitations to ADR amounted to unreasonable refusal to engage with ADR and should, therefore, be penalised in costs. The Court of Appeal agreed. Briggs LJ held that a party's silence in the face of an invitation to ADR would, as a general rule, be regarded as unreasonable behaviour which would result in an adverse costs order being made. This was regardless of whether there may have been justifiable grounds to reject the invitation. Briggs LJ's judgment is heavily focused on mediation, discussing the success rates of mediation using figures from the CEDR and the Court of Appeal Mediation Scheme and the general nature and virtues of a settlement through mediation. As argued above, although the facts of some of the ADR authorities specifically dealt with mediation, including PGF, Briggs LJ's judgment adopts a more balanced approach to the notion of ADR and the need for positive engagement with invitations to ADR. Briggs LJ spoke of the need for the parties themselves, without necessarily the court's assistance, to consider suitable ADR procedures and engage with ADR in trying to settle their disputes, which was also required in the interest of the proportionate use of limited court resources. As well as strong policy reasons for the

84 Rolf (n 83) [48].

85 [2013] EWCA Civ 234.

86 Ibid [2].

87 [2013] EWCA Civ 1288. 
parties to engage with an invitation to ADR, there were also strong practical reasons, including opening up discussions between the parties on the most appropriate ADR procedure for the dispute. In this regard, Briggs LJ referred to the possibility of judicialENE as a potential ADR procedure which may be appropriate, in which case there is an expectation that the parties would discuss and try to resolve these issues. A positive engagement with ADR would also serve the policy of proportionality including the parties choosing a different type of ADR procedure. In the penultimate paragraph of his judgment, Briggs LJ warned of the folly of ignoring ADR when he said:

... this case sends out an important message to civil litigants, requiring them to engage with a serious invitation to participate in ADR, even if they have reasons which might justify a refusal, or the undertaking of some other form of ADR, or ADR at some other time in the litigation. To allow the present appeal would, as it seems to me, blunt that message. The court's task in encouraging the more proportionate conduct of civil litigation is so important in current economic circumstances that it is appropriate to emphasise that message by a sanction which, even if a little more vigorous than I would have preferred, none the less operates pour encourager les autres. ${ }^{88}$

Briggs LJ's reference to 'the undertaking of some other form of ADR' reflects the wider understanding and appreciation of ADR as a term which embraces a variety of procedures, not just mediation. Even though the facts of the case concerned the claimant's invitation to mediation, the judgment embraces ADR in its widest possible sense. This is consistent both with Briggs LJ's comments in his Chancery Modernisation Review and his CCSR, and it is this judicial understanding that must prevail in order to avoid the continued development of the two-stream civil justice process which Ward LJ alluded to in Wright.

Judicial ENE was recently given strong judicial support in the recent Court of Appeal decision of Lomax. ${ }^{89}$ The issue in Lomax was whether, as part of its case management powers under CPR 3.1(2)(m), the court could compel the defendant to engage with judicial ENE. At first instance, Parker $J$ held that she could not order an ENE in circumstances where one of the parties did not consent for such an order to be made. A close analysis of the relevant court rules, including the language of CPR 1.4(1)(e), the rule dealing with the alternative dispute resolution aspect of the overriding objective, were directed at facilitation rather than compulsion and therefore the courts did not possess the power to compel parties to ENE. However, that conclusion did not detract from Parker J's view that this was a case 'which cries, indeed screams out, for a robust judgeled process to focus on the legal and factual issues ... and perhaps even craft a proposed solution for the parties to consider'. ${ }^{90}$

Giving the judgment of the Court of Appeal, Moylan LJ noted that, because the wording of CPR r.3.1 $(2(\mathrm{~m})$ did not contain an express requirement for party consent before an ENE could be ordered, the issue was whether such a limitation could be implied into the rule. Moylan LJ held that if the intention had been to require the parties' consent, then it would have been easy to make this clear within the rule and the absence of express words requiring party consent was 'a powerful indication that consent is not required'. ${ }^{91}$ It followed that there was no reason to imply into CPR r.3.1(2)(m) any limitation on the courts' power to order an ENE hearing. Such an interpretation 'would

88 Ibid [56].

$89 \operatorname{Lomax}(\mathrm{n} 19)$.

90 Ibid [123].

91 Ibid [30]. 
be inconsistent with elements of the overriding objective, in particular the saving of expense and allotting to cases an appropriate share of the court's resources, and would, therefore, be contrary to rule 1.2(b) ${ }^{92}$ Did ordering an ENE prevent the parties from having their dispute determined by the courts? Moylan LJ answered in the negative. His Lordship explained that, in the event that the matter could not be settled as a result of the parties engaging with an ENE this 'did not, in any material way, obstruct a party's access to the court'. ${ }^{93}$ At most, an ENE was an additional step in the court process and therefore was 'not in any sense an "unacceptable constraint" on the parties' rights to access the courts'. ${ }^{94}$ Court-ordered ENE was, in Moylan LJ's view, 'a step in the process which can assist with the fair and sensible resolution of cases' ${ }^{95}$ In fact, an ENE in which a judge provides his or her neutral evaluation of the merits of the parties' respective positions had the positive effect of focusing the parties' minds on the issues and on settlement which would save both the parties and the courts time and cost.

The decision in Lomax is significant for a number of reasons. The Court of Appeal adopted the correct approach on the contentious issue of whether compelling noconsenting parties to ENE undermines or restricts the parties' rights to access the courts. ENE, like mediation, is not a hindrance to the parties' rights to access the courts because the parties are at liberty to choose not to be bound by the expert's evaluation and to revert to the court process for judicial determination of their dispute. It is a procedure which, as Moylan LJ helpfully explained, assists the parties to obtain a judge's opinion on the merits of the parties' respective positions and to focus their minds on settlement; the parties are not bound by that opinion unless they choose to be. Also, the wording of CPR r.3.1(2) (m) is deliberately widely drafted with the intention of providing the courts with the necessary discretion to manage disputes effectively in order to further the overriding objective. Ordering ENE in appropriate cases is an important part of those judicial functions. To accept the argument that party consent should be implied into CPR r.3.1(2)(m) would be to place an unnecessary fetter on the court's case management powers and undermine the overriding objective of dealing with cases justly and at proportionate cost. It would also beg the question of which other aspects of the court's case management powers were subject to party consent given the complete absence of any explicit reference to consent in CPR r.3.1. The decision, therefore, is consistent with the central aims of the overriding objective and, more significantly, upholds and gives effect to the principle of proportionality. ${ }^{96}$ Accordingly, the courts should consider the effect decisions in individual cases have on the civil justice system as a whole. A commitment to the principle of proportionality reduces the possibility of achieving substantive justice as it requires a compromise between the resources made available to

92 Ibid [32].

93 Ibid [26].

94 Ibid [26].

95 Ibid [27].

96 For a detailed analysis of the overriding objective and the principle of proportionality, see John Sorabji, 'The Road to New Street Station: Fact, Fiction and the Overriding Objective' [2012] European Business Law Review 77; and John Sorabji, 'Prospects for Proportionality: Jackson Implementation' (2013) 32 Criminal Justice Quarterly 213. Lord Clarke MR explained the importance of the principle of proportionality when he said: 'Our civil justice system has always been committed to ensuring justice is achieved economically, efficiently, in a timely fashion, and through the application of equality of arms. There was nothing novel there. You need simply look to the previous civil justice reform reports to see that. No, the significant difference between the Woolf reforms and what had gone before was the commitment to the proportionality principle.'; A Clarke, 'Proportionate Costs from Woolf to Jackson' (The Law Society 2009) (unpublished) at [8]. 
each claim and securing a substantively just decision in individual claims. ${ }^{97}$ In this respect, judicial ENE provides a unique opportunity to the parties because the issues are dealt with in an authoritative manner whilst also upholding the principle of proportionality.

Finally, although the decision in Lomax was only concerned with judicial ENE as part of the court's case management powers, it also demonstrates a judicial shift away from a narrow perception and application of ADR as simply equating to mediation and dispute resolution as merely equating to a two-stream process of mediation and litigation. Parker J at first instance was willing to critically consider the nature of mediation and ENE and to identify the procedure which was most suited to the circumstances of the case rather than simply focusing and recommending mediation. Parker J noted that: 'Mediation (even by a legally trained mediator, if one should be found to assist where the issues were specialised) is unlikely to approach the issues in an authoritative way, as Norris J said in Seals.' In his judgment, Moylan LJ also discussed in detail the nature of ENE and its practical and economic virtues for the courts and the parties. Thus, both decisions reflect a wider understanding and appreciation of what is meant by dispute resolution and the judicial activities related to ADR. The classic perception of the role of a judge is limited to formal adjudication. In reality, however, the promotion of settlement is also a mainstream judicial activity, ${ }^{98}$ and perhaps even more so than formal adjudication considering the fact that a vast majority of claims issued in the civil courts are undisputed. ${ }^{99}$ This melding of ADR techniques with the traditional exclusively adjudicative role of the courts has been conceptualised as judicial dispute resolution by scholars. ${ }^{100}$ The claimant's choice of ENE as opposed to simply opting for mediation caused Parker J to engage with a wider consideration of dispute resolution, including engaging in a critical comparison between ENE and mediation. Therefore, the decision in Lomax provides fertile ground for a future judicial culture shift towards a wider understanding of ADR and dispute resolution.

\section{Solutions and conclusion}

It has been shown that the increasingly strong focus and promotion of mediation by the judiciary, through decided cases, has created judicial mediation bias and that this, in turn, has distorted and narrowed the concepts of ADR and dispute resolution so that there exist two dominant dispute resolution streams: litigation and mediation. There is evidence from the jurisprudence that mediation is used synonymously with ADR. Aside from Briggs LJ's judgment in PGF, there also appears to be a lack of attention to and promotion of other forms of ADR, which may provide better outcomes for the parties. Although Lomax is a positive step forward, the overwhelming ADR jurisprudence is focused on the promotion of mediation.

Given the actual and potential adverse consequences of judicial mediation bias, there is a need for a culture change in the manner in which the judiciary approaches and promotes ADR within the jurisprudence. This is particularly significant because the judiciary must not only dispense substantive justice but must also ensure that procedural justice is achieved when applying the overriding objective - this in turn contributes to the

97 John Sorabji, English Civil Justice after the Woolf and Jackson Reforms: A Critical Analysis (Cambridge University Press 2014) 168-89.

98 Michael Alberstein, 'Judicial Conflict Resolution (JCR): A New Jurisprudence for an Emerging Judicial Practice' (2015) 16 Cardozo Journal of Conflict Resolution 885.

99 Lord Justice Briggs, Civil Court Structure Review: Final Report (TSO 2016) para 6.109.

100 For a thorough analysis of this subject see Tania Sourdin and Archie Zariski (eds), The Multi-Tasking Judge: Comparative Judicial Dispute Resolution (Thomson Reuters 2013). 
development of procedural jurisprudence. The Court of Appeal, in particular, is responsible for overseeing the development of civil procedure and for providing valuable judicial leadership. That leadership should ensure that subsequent ADR authorities reflect a wider and more consistent notion of ADR. In this regard, a simple solution is to call on the judiciary to alter its approach to and understanding of the notion of dispute resolution and ADR and to embrace, encourage and promote a variety of ADR procedures. This may be done through greater focus on educating and training the judiciary, though the Judicial College, ${ }^{101}$ on all aspects of ADR and encouraging it to adopt a more pragmatic approach, similar to Sander's 'screening' of disputes. Parties would be encouraged to consider a range of options and the courts could actively engage in a wider 'ADR conversation' with them. Several powers supporting this approach exist in the CPR, including the overriding objective, the court's case management powers, the ability for the court to stay proceedings in favour of settlement, ${ }^{102}$ and the powers to make ADR orders. ${ }^{103}$ Here, leadership from the Court of Appeal through decided ADR cases is vital in effecting a culture change so that the wider notion of dispute resolution and ADR is used as a norm.

What practical solutions could bring about a clearer, more consistent and wider understanding of ADR within the civil justice system? What changes, beyond simply calling for a culture change, can be made, to avoid entrenching an 'ADR tunnel vision'?

In addition to training judges on the wider concept of dispute resolution and the nature and variety of ADR procedures, the Judicial College would be the most effective forum to train and develop the skills of judges to actually conduct certain ADR procedures, in particular, judicial-ENE. The power of the courts to undertake an ENE was recognised and confirmed by Norris $J$ in Seals and was, more recently, strongly endorsed by Parker J in Lomax v Lomax. ${ }^{104}$ The courts should be brave and embrace their case management powers in ordering parties to judicial ENE. The Judicial College should focus on delivering a structured training programme that focuses on developing the essential skills that judges would need to not only recommend ENE to the parties but to also conduct an ENE.

Structural changes are required within the court process to change culture for both the judges and the parties. Structural changes help to reinforce cultural and conceptual changes: for example, Lord Woolf's philosophy of settlement was a fundamental culture shift in the resolution of disputes and was given force through the CPR. Thus, any culture shift away from judicial mediation bias to a wider application of ADR requires important structural changes. The OCMC (with its potential to expand its jurisdiction to cover higher-value and more complex disputes) provides the greatest opportunity to introduce those changes, which must take place both at stage one and two of the OCMC.

The OCMC is under construction and is being rolled out in stages. Stage one is currently operational and is subject to a pilot which allows LiPs and lawyers to upload a claim and defence. ${ }^{105}$ It is currently an automated system and provides very little information to prospective litigants on ADR options. It simply states that the prospective

101 The Lord Chief Justice is responsible for arrangements for training the courts' judiciary in England and Wales under the Constitutional Reform Act 2005. The Senior President of Tribunals has an equivalent responsibility in relation to judges and members of the tribunals within the scope of the Tribunals, Courts and Enforcement Act 2007. These responsibilities are exercised through the Judicial College.

102 CPR 26.

103 Admiralty and Commercial Courts Guide (10th edn, HM Courts and Tribunals Service 2017).

104 [2019] EWHC 1267 (Fam).

105 CPR Practice Direction 51R and CPR PD 51S. 
claimants should consider resolving their disputes by speaking to the other side (i.e. using negotiation) or suggests that the parties may consider using mediation. However, as it currently stands, stage one is wholly inadequate in educating and signposting parties to a wider variety of ADR procedures, or explaining the nature of those procedures and how they may be appropriate for certain types of disputes. If parties are to be better educated and informed of the concept of ADR and are to actively consider and engage with ADR, there must be a greater emphasis on the range of ADR procedures (through an explanation of each type) and signposting to other dispute resolution channels, such as the Ombudsman service, which may be more appropriate and effective in the resolution of different disputes. Stage one would also provide an effective opportunity to introduce CDR and educate parties about its nature and virtues. Clearly, CDR would be more appropriate for the future and as the OCMC's jurisdiction expands to encompass highervalue and more complex disputes.

Aside from achieving early settlement, the strength of an enhanced ADR education and signposting approach at stage one is that if the matter cannot be settled then the parties will proceed to stage two with a deeper and more informed understanding of the nature of ADR. It also means that the parties are in a better position to engage in an 'ADR conversation' with each other and with the court officer when considering and deciding on the most appropriate ADR procedure.

Stage two must effectively integrate a variety of ADR procedures and not simply focus on mediation. Although Briggs LJ's vision of stage two of the OCMC is to have a greater emphasis on ADR, this must become a reality and not simply reinforce mediation as the only ADR procedure.

The current proposal is for stage two of the OCMC to include opt-out mediation for cases up to $f 300$ : that is, the dispute will automatically be referred to mediation unless one or both of the parties elect not to have their dispute referred to mediation. ${ }^{106}$ Although the integration of ADR within the process is to be welcomed, the current proposals to focus simply on mediation as the only ADR procedure at stage two of the OCMC has the obvious danger of reinforcing mediation bias and preserving, rather than transforming and widening, the narrow understanding of dispute resolution. It is this stage, together with the changes to stage one in signposting and educating the parties, that has the greatest potential to promote a wider understanding and application of ADR and dispute resolution. As the jurisdiction of the OCMC expands to higher-value and more complex disputes, stage two should also expand by integrating a wider variety of ADR procedures, in particular ENE, and the courts should continue to exercise their cost powers to penalise parties for unreasonably refusing to engage with the process. As recently illustrated in the case of Thakkar $v$ Patel, ${ }^{107}$ the courts are willing to exercise their costs powers to penalise parties for failing in their ADR duty. As Jackson LJ made clear in Thakear:

The message which this court sent out in PGF II was that to remain silent in the face of an offer to mediate is, absent exceptional circumstances, unreasonable conduct meriting a costs sanction, even in cases where mediation is unlikely to succeed. The message which the court sends out in this case is that in a case where bilateral

106 D Phillips, Programme Director HM Courts and Tribunal Service, 'Courts, Tribunals and Regional Tier' (HM Courts and Tribunal Service Event, 11 Match 2019) <https://assets.publishing.service.gov.uk/government/uploads/system/uploads/attachment_data/file/7853 24/Civil_reform_event_11_March_2019.pdf>.

107 Thakkar (n 11) (emphasis added). 
negotiations fail but mediation is obviously appropriate, it behoves both parties to get on with it. 108

This proposal also envisages that judges (not court officers) will actively participate at stage two only to conduct ENE for the parties. If the matter cannot be settled following judicial-ENE, then the matter will proceed to stage three for judicial determination, with a different judge. Two types of disputes, small construction disputes and boundary disputes, can be taken as examples of disputes which may be more appropriate for ENE at stage two rather than mediation. These types of cases would be appropriate for ENE because the issues in dispute will require a degree of expert knowledge of the subject matter (e.g. measuring and determining boundaries and understanding technical construction terminology).

A review of the ADR jurisprudence reveals that the Court of Appeal has, whether intentionally or not, 'carved out' boundary and small construction disputes (i.e. those falling outside the compulsory adjudication scheme) ${ }^{109}$ as being appropriate for settlement through mediation. Indeed, Ward LJ in Burchell and Rix LJ in Rolf made clear their views that small construction disputes were suitable for mediation.

As for boundary disputes, Elias LJ in Oliver v Symons ${ }^{110}$ lamented that the matter before him 'was crying out for mediation, even assuming that it could not have been settled more informally than that. It ought never to have come near a court, and with a modicum of good will on both sides, it would not have done so.' 111 In Faidi v Elliott Corporation ${ }^{112}$ the Court of Appeal strongly endorsed the use of mediation in resolving neighbour disputes when Jackson LJ said this was: 'precisely the sort of outcome which a skilled mediator could achieve, but which the court will not impose'. In the same case, Ward LJ expressed his enthusiasm for mediation in the following manner: 'I wish enthusiastically to associate myself with the observations of my Lords on the desirability of mediation in neighbourhood disputes.' ${ }^{113}$ Further, in Bramwell and Others $v$ Robinson, ${ }^{114}$ a right-of-way dispute, the parties did attempt mediation a number of times but could not reach a settlement. Despite this, HHJ Brehrens insisted that mediation would still have been preferred because 'as with many such disputes it would have been far better if it could have been resolved amicably or with the assistance of an experienced mediator'. ${ }^{115}$

Jackson LJ has also expressed his strong preference for the use of mediation for boundary disputes. In his Final Report he stated: 'Domestic boundary disputes and similar property disputes between neighbours are particularly well suited to mediation. Judicial encouragement in this regard at an early stage is highly beneficial for the parties. ${ }^{116}$

108 Ibid [30].

109 Housing Grants, Construction and Regeneration Act 1996, Part II.

110 [2012] EWCA Civ 267.

111 Ibid [1]. See also the comments of Ward LJ in ibid [53]: 'All disputes between neighbours arouse deep passions and entrenched positions are taken as the parties stand upon their rights seemingly blissfully unaware or unconcerned that they are committing themselves to unremitting litigation which will leave them bruised by the experience and very much the poorer, win or lose.'

112 [2012] EWCA Civ 287.

113 Ibid [30]. Another neighbour dispute was Bradley v Heslin [2014] EWHC 3267 (Ch) in which Norris J said the 'entrenchment of positions' was a regrettable characteristic of neighbour disputes and mediation was more likely to produce an 'outcome satisfactory to both parties'.

114 [2016] EWHC B26 (Ch).

115 Ibid [1].

116 Jackson (n 3) para 4.12. 
But why should these types of disputes be taken as being most suitable for mediation? It is accepted that mediation has its practical and economic virtues and may provide the parties in neighbour and small construction disputes with a solution - there is no argument there. There is, however, an argument against judicial promotion of mediation as the default ADR procedure for the resolution of those types of disputes, without proper consideration and promotion of other ADR procedures which may provide better outcomes and higher levels of settlement. Those disputes would benefit greatly from judicial-ENE or CDR. Given that these types of disputes typically involve individuals who are emotionally involved in the particulars of the dispute, the parties often take very entrenched positions. Judicial-ENE would provide an expert option on the merits of the arguments, which the parties may feel confident in accepting, either to settle the matter or at least narrow the issues.

As the jurisdiction of the OCMC expands to encompass higher-value and more complex disputes, information on the nature of CDR should be incorporated during stage one so that the parties are educated, informed and signposted as regards CDR. This proposal could follow the Mediation Information and Assessment Meeting (MIAM) ${ }^{117}$ model in family disputes. ${ }^{118}$ Separating couples are obliged to attend a MIAM before making certain kinds of applications to the family courts to obtain a court order. The aim of MIAMs is to provide the parties with information about mediation and for them to consider whether their differences could be resolved through mediation. Drawing inspiration from MIAMs, parties to civil disputes could be signposted to information on the nature of CDR and how it operates, as well as providers of CDR services.

Although judicial-ENE may be effective, the thorny issue of the lack of resources remains. The Ministry of Justice is not protected from austerity policies and the civil justice system continues to see its budget cut. However, investment in the training and development of judicial-ENE is an investment worth making because it will result in the more efficient management and settlement of disputes. By developing a wider approach to dispute resolution and ADR procedures, especially judicial-ENE which requires active judicial participation, judges will be better equipped to manage and dispose of a variety of disputes. This would assist in the current aims of the Ministry of Justice in modernising the courts and the judiciary. This potential benefit will reinforce some of the principal aims of the recent Court and Tribunals (Judiciary and Functions of Staff) Act 2018.

The Act was introduced to allow judges to work more flexibly by being deployed across a range of cases and to provide for the undertaking of some judicial functions by HM Courts and Tribunal Service staff. The Act contains three substantive sections and one schedule. Section 1 changes existing legislation to remove restrictions on how judges can be deployed, enabling judges to hear a wider scope of cases. Section 2 makes minor changes to the law concerning some judicial titles, and section 3 and schedule 1 provide for court and tribunal staff to carry out some judicial functions and to provide legal advice to judges. By delegating some judicial functions to court staff, section 3 and schedule 1 can provide judges with greater opportunities and scope to be trained to conduct ENE and other forms of ADR at stage two of the OCMC. This would allow judges to develop a wider understanding and appreciation of ADR and

117 Introduced by s 10 (1) of the Children and Families Act 2014.

118 For an assessment of MIAMs, see A Moore and S Brookes, 'MIAMs: A Worthy Idea, Failing in Delivery' (2018) 1 Private Client Business 32-39. For an explanation of how MIAMs work in practice, see J Edwards, 'Closer Collaboration between the Judicial and Mediation Communities: Part 1: Mediation/MIAMs - How They Work in Practice’ (2016) 46 (September) Family Law 1168-71. 
thus diminish the existence of judicial mediation bias. It will also encourage judges to broaden their skills so that they are not only aware of ADR procedures but are also actively providing judicial-ENE and exposing themselves and the parties to its potential benefits.

The concept and practice of dispute resolution has evolved from court-based judicial determination as the only means of resolving civil claims to a wider concept which encompasses alternatives to the court process, including ENE and CDR. However, as this paper has revealed, the overzealous judicial emphasis on mediation has undermined and distorted dispute resolution and ADR so that a two-system process exists within the civil justice process: litigation and mediation. This situation is wholly unsatisfactory for disputing parties who ultimately bear the cost of engaging with the civil court process. Therefore, it is only through a judicial culture shift and procedural changes, including grasping the opportunities provided by the OCMC, that a wider understanding and application of dispute resolution and ADR can be restored and preserved. 